\title{
Silicosis and Dust Control
}

\author{
—Vermont's Granite Industry-
}

BY HARRY B. ASHE, B.S.

$\mathrm{V}$ ERMONT granite is a heterogeneous mixture of approximately 60 percent feldspar, 30 percent quartz, 15 percent mica, and 5 percent miscellaneous silicates. Quartz is, of course, the black sheep of the group of minerals which comprise this monumental stone.

Pneumatic tools came into general use between 1895 and 1900, accompanied by a tremendous increase in dust production over that produced by hand tools. Industrywide dust control for all dust-producing operations had its beginning in 1937. Hence, the period of greatest dust exposure in the Vermont granite manufacturing industry is about 40 years.

\section{A Bench Mark}

The year 1937 is a bench mark in the Vermont granite manufacturing industry: A program of dust control for all dust-producing operations was put into effect by the industry. A division of industrial hygiene was created in the Vermont Department of Health, and for

Mr. Ashe, director of the division of industrial hygiene, Vermont Department of Health, since 1946, served as program chairman of the American Conference of Governmental Industrial Hygienists, 1953-54, and as chairman, 1954-55. This paper was presented at the 17th annual meeting of the conference in Buffalo, 1955.

Vol. 70, No. 10, October 1955 many years it concentrated most of its efforts in improving working conditions in the industry. The division purchased a portable X-ray machine and began a yearly $\mathbf{X}$-ray program, which is still in effect.

During the period 1924-26, dust exposures in this industry were reported by the Public Health Service to be about 1 to 200 million particles per cubic foot of air. Granite cutters who suffered the most severe exposure averaged an exposure of about 60 million particles per cubic foot of air (1). Since the beginning of plant-wide dust control in 1937, the dust exposure has been gradually reduced.

Recent dust counts in the industry indicate a general air dustiness of 1 to 2 million particles per cubic foot of air, with few individual operators exposed to greater than 5 million particles per cubic foot of air. Recirculation of dust collectors has been completely discontinued, and dry dust-producing operations in the industry are provided with an approved type dust collector. Every exhaust unit in the industry is inspected by the division of industrial hygiene at least twice a year, and detailed reports are sent to the individual manufacturer with a mandatory compliance order wherever corrections or improvements are necessary.

During 1937 and 1938 there was a very definite effort to encourage men to visit the division office for an X-ray at any time during their free hours. During that period, the division $\mathrm{X}$-rayed 805 granite workers for the first time. 
Table 1. Number of granite workers $X$-rayed, Vermont Department of Health, 1937-54

\begin{tabular}{|c|c|c|c|}
\hline \multirow{2}{*}{ Year } & \multicolumn{3}{|c|}{ Number X-rayed } \\
\hline & $\begin{array}{l}\text { First } \\
\text { time }\end{array}$ & $\begin{array}{c}\text { Re- } \\
\text { checks }\end{array}$ & Total \\
\hline $\begin{array}{l}1937 \\
1938 \\
1939 \\
1940 \\
1941 \\
1942\end{array}$ & $\begin{array}{r}645 \\
160 \\
89 \\
90 \\
137 \\
83 \\
86 \\
38 \\
37 \\
109 \\
62 \\
203 \\
36 \\
239 \\
475 \\
209 \\
191 \\
131\end{array}$ & $\begin{array}{r}0 \\
211 \\
169 \\
155 \\
308 \\
251 \\
212 \\
183 \\
248 \\
235 \\
325 \\
452 \\
320 \\
698 \\
519 \\
1,178 \\
1,262 \\
1,306\end{array}$ & $\begin{array}{r}645 \\
371 \\
258 \\
245 \\
445 \\
334 \\
298 \\
221 \\
285 \\
344 \\
387 \\
655 \\
356 \\
937 \\
994 \\
1,387 \\
1,453 \\
1,437\end{array}$ \\
\hline Total & 3,020 & 8,032 & 11,052 \\
\hline
\end{tabular}

Froin 1938 to 1950 , evening clinics were held for granite workers in the division office. Results are shown in table 1 . However, many men were not availing themselves of this service provided by the State of Vermont, and in 1950 arrangements were made with the various manufacturers to set up our portable X-ray machine in their establishments so that men could be X-rayed on company time. By this change of procedure, 937 and 994 men were $\mathrm{X}$-rayed in 1950 and 1951, respectively.

\section{Mobile X-ray Unit}

During the summer of 1951 we conceived the idea of constructing a mobile $\mathrm{X}$-ray unit whereby our X-ray machine could be transported to every shed in the area and our service offered to the men at a distinct saving to the manufacturer. This unit was put into service in the fall of 1951 with an increase in participation of about 400 men a year.

The 26-foot trailer consists of a small room in the rear for occupational histories, a darkroom for changing films, an $\mathrm{X}$-ray compartment in the middle, and a dressing room in the front. A 3,000-watt, 220, 110-volt generator supplies the power, and a State-owned auto- mobile provides the transportation. Leadlined plywood is used in the interior construction to protect operating personnel from stray radiation.

This mobile $\mathrm{X}$-ray unit, designed to $\mathrm{X}$-ray men in dusty trades at their place of employment, was put into operation in September 1951. It has traveled 8,000 miles and taken 13,776 $\mathrm{X}$-rays. The industries covered are granite, marble, slate (quarrying and finishing); asbestos (quarrying and milling); talc (mining and milling); copper (mining and processing); foundries (gray iron). The cost of the unit follows :

26-ft. Travelo trailer, custom built, with furnishings -.....

Picker portable $\mathrm{X}$-ray machine, 15 ma., 8-step voltage control, $14^{\prime \prime}$ by $17^{\prime \prime}$ plates_._._._- 1,350

Pass box, casette holder, casettes, and other accessories 3,000-watt Onan electric plant, installed...-..State-owned automobile, overload springs, trailer hitch, accessories 2,727

Total cost $\$ 8,864$

\section{$1937-1938$}

Approximately 2,400 men were employed in the Vermont Barre Belt granite manufacturing district in cach of the years 1937 and 1938. Of the 805 men $\mathrm{X}$-rayed, 365 had silicosis (45.3 percent); and 143 had silicosis with possible infection ( 17.9 percent).

All cases with definite X-ray evidence of nodular silicosis, whether it be early, moderately advanced, far advanced, or complicated with infection, are grouped together. In the category "silicosis plus possible infection," the infection is presumed to be tuberculosis. However, in these data (table 2) there has been no attempt to prove the existence of infection. It is very probable that a number of the men listed in this category have nothing more than a conglomerate silicosis. Some of them may have cavitation and positive sputa. For the purpose of this paper they are likewise grouped together.

\section{$1952-1954$}

The 3 years from 1952-54 have been taken for comparison with 1937-38 inasmuch as the 
Table 2. Number of granite workers $X$-rayed and found to have silicosis, Vermont Department of Health, 1952-54

\begin{tabular}{|c|c|c|c|c|c|c|}
\hline \multirow{2}{*}{ Number of men } & \multicolumn{2}{|c|}{1952} & \multicolumn{2}{|c|}{1953} & \multicolumn{2}{|c|}{1954} \\
\hline & Number & Percent & Number & Percent & Number & Percent \\
\hline $\begin{array}{l}\text { On payroll } \\
\text { Working, day of } \mathrm{X} \text {-ray } \\
\mathrm{X} \text {-rayed. } \\
\text { On payroll, previously } \mathrm{X} \text {-rayed but not in indicated year } \\
\text { On payroll, X-rayed at least once } \\
\text { Found with silicosis } \\
\text { On payroll, diagnosis silicosis, } \mathrm{X} \text {-rayed at least once, } \\
\text { but not in indicated year } \\
\text { On payroll, diagnosis silicosis } \\
\text { Found with silicosis plus possible infection } \\
\text { On payroll, diagnosis silicosis plus possible infection, } \\
\mathrm{X} \text {-rayed at least once, but not in indicated year } \\
\text { On payroll, diagnosis silicosis plus possible infection. }\end{array}$ & $\begin{array}{r}1,736 \\
1,616 \\
1,387 \\
185 \\
1,572 \\
274 \\
45 \\
319 \\
54 \\
4 \\
58\end{array}$ & $\mid \begin{array}{r}18.4 \\
3.3\end{array}$ & $\begin{array}{r}1,810 \\
1,786 \\
1,453 \\
232 \\
1,685 \\
253 \\
69 \\
322 \\
44 \\
18 \\
62\end{array}$ & $\left|\begin{array}{r}17.9 \\
-3.4\end{array}\right|$ & $\begin{array}{r}1,809 \\
1,691 \\
1,437 \\
261 \\
1,698 \\
219 \\
75 \\
294 \\
28 \\
14 \\
42\end{array}$ & $\begin{array}{r}84 . \overline{9} \\
9 \overline{3} . \overline{9} \\
1 \overline{6} . \overline{2} \\
-2 . \overline{3}\end{array}$ \\
\hline
\end{tabular}

mobile X-ray unit was in operation during these years, and the greatest cooperation was received from both employer and employee. The data in table 2 indicate the proportion of persons in the Vermont granite manufacturing industry who were $\mathrm{X}$-rayed during these years and found to have silicosis.

The gradual decrease in the incidence of silicosis from a high of 45.3 percent in 1937 and 1938 to a low of 16.2 percent in 1954 may be attributed to two causes: dust control and silicotics leaving the industry for one reason or another. 'The incidence of silicosis with possible infection has been reduced from 17.9 percent to 2.3 percent over the same period.

The X-ray program began in 1937 . Consequently, there could be no backlog of X-ray data then. Hence, the data for the years 1937 and 1938 cannot be compared on the same basis with data for the years 1952-54. However, we believe, the data presented here demonstrate an apparent striking decrease in the incidence of this occupational disease in a very hazardous industry. The majority of the 2,400 men employed in the industry in 1937 probably had more than 10 years experience; only 34 percent of these were $\mathrm{X}$-rayed, and 45 percent of those $\mathrm{X}$-rayed were found to have silicosis. It is gen- erally believed that if it had been possible to examine the chest $\mathrm{X}$-rays of every man employed in the industry at that time the incidence of silicosis might even have been higher. In 1954, for contrast, of all the men on the payroll, 18.4 percent were found to have silicosis (or 19.8 percent of those who had X-rays). Participating in the program, however, were 90.6 percent of the employees.

\section{Summary}

Our X-ray program started in 1937. Dust control started the same year and has gradually improved ever since. The State health department has not to this day discovered a case of silicosis in any man who has worked only in the Vermont granite manufacturing industry since 1937. It is our contention that this remarkable record is mainly due to effective dust control within the industry.

\section{REFERENCE}

(1) Russell, A. E., Britten, R. H., Thompson, L. R., and Bloomfield, J. J.: The health of workers in dusty trades. II. Exposure to siliceous dust (granite industry). Public Health Bulletin No. 187. Washington, D. C., U. S. Government Printing Office, 1929. 